\title{
Frequência de anticorpos contra o herpesvírus bovino 1 (BoHV-1) em bubalinos (Bubalus bubalis) de corte não vacinados provenientes do município de Ponta Grossa, Paraná
}

John Clinton Henrique ${ }^{[a]}$, Juliana Fritzen ${ }^{[b]}$, Amauri Alcindo Alfieri ${ }^{[b]^{*}}$, Júlio Augusto Naylor Lisbôa ${ }^{[b]}$, Rodrigo Azambuja Machado de Oliveira[c] Ivan Roque de Barros Filho[ ${ }^{[d]}$

\footnotetext{
[a] Médico veterinário autônomo.

[b] Programa de Pós-gradução em Ciência Animal, Universidade Estadual de Londrina (UEL), Londrina, PR, Brasil

[c] Centro de Ensino Superior dos Campos Gerais (CESCAGE), Ponta Grossa, PR, Brasil

${ }^{[\mathrm{d}]}$ Docente do curso de Medicina Veterinária, Universidade Federal do Paraná (UFPR), Curitiba, PR, Brasil
}

*Autor correspondente

e-mail: alfieri@uel.br

\section{Resumo}

As infecções herpéticas provenientes do herpesvirus bovino 1 (BoHV-1) apresentam grande importância devido a elevadas taxas de dispersão no ambiente. Os bovinos são hospedeiros naturais do BoHV-1, porém infecções pelo vírus têm sido relatadas em outras espécies de ruminantes, inclusive bubalinos. 0 presente trabalho teve como objetivo determinar a frequência de amostras frente ao BoHV-1 em bubalinos de corte não vacinados, por meio da técnica de Virusneutralização (VN). Para isso foram coletadas amostras de soro sanguíneo de animais oriundos dos municípios de Ipiranga e Ponta Grossa, sendo essas encaminhadas para o Laboratório de Virologia Animal da Universidade Estadual de Londrina (UEL). Foram examinadas 14 amostras de sangue provenientes de bubalinos de corte criados em regime extensivo e intensivo, no período compreendido entre junho e dezembro de 2015. Os animais eram machos e fêmeas de diferentes categorias, com idade entre 6 e 50 meses, não vacinados contra BoHV-1. A coleta de amostras sanguíneas deuse através da venopunção da veia coccígea. As amostras foram mantidas refrigeradas em caixas isotérmicas, para posterior processamento laboratorial com a finalidade de obtenção de soro sanguíneo. Posteriormente, o material foi novamente armazenado em tubos a vácuo e mantidos congelados para serem encaminhados para o Laboratório de Virologia Animal da Universidade Estadual de Londrina (UEL), onde foi feita a leitura e processamento das amostras para o teste de VN. Das amostras sorológicas avaliadas, 11/14 (78,5\%) geraram anticorpos neutralizantes frente ao BoHV-1. As amostras restantes 3/14 (21,5\%) não foram reagentes. 0 teste de VN é amplamente usado em inquéritos epidemiológicos, sendo considerado um teste padrão para detecção de anticorpos contra o BoHV-1 em ruminantes. No Paraná, estudo pioneiro realizado por Oliveira (2013) 
utilizando a Reação em Cadeia da Polimerase (PCR) para a identificação do BohV-1 em amostras de gânglio trigêmeo, em bovinos de corte de todas as mesorregiões do estado, evidenciou a presença do genoma viral em $14,2 \%$ dos bovinos amostrados. Contudo, a análise sorológica realizada no presente estudo evidencia uma elevada circulação do BoHV-1 em bubalinos criados em diferentes sistemas de produção. Ademais, embora tratem de métodos diagnósticos distintos, o presente estudo comprova a infecção herpética interespecífica em bubalinos criados na região centro-oriental do estado. Estudo pioneiro no estado, sobre a soroprevalência do BoHV-1 em amostras bubalinas nos municípios de Antonina e Doutor Ulysses, evidenciou uma positividade de $90 \%$ (18/20) dos animais. Já no Rio Grande do Sul, trabalhos mostram que a prevalência de herpesvirus em bubalinos varia de 30,1 \% a 46,9\%. A presença do BoHV-1 em bubalinos na região amostrada mostrou-se elevada, e os dados são fundamentais para a adoção de medidas mitigatórias para o controle do agente. 